\title{
Rides from Others
}

National Cancer Institute

\section{Source}

National Cancer Institute. Rides from Others. NCI Thesaurus. Code C159752.

Getting rides from other people for transportation. 